\title{
MICROBIOLOGICAL ANALYSIS OF WATER USED IN HYDROTHERAPY
}

\section{PERESTRELO M. F. (1), NORBERG A. N. (1), GUERRA-SANCHES F. (1),} TORRES A. C. (1), PILE E. (2)

(1) Iguaçu University, Nova Iguaçu, Rio de Janeiro, Brazil; (2) National Institute of Agricultural Research and Development, INIDA, Cape Verde.

ABSTRACT: Water used in hydrotherapy units of Nova Iguaçu and Nilópolis, Rio de Janeiro State, Brazil, was microbiologically analyzed. Thirty samples (5ml each) were weekly collected from September 2001 to June 2002 before the beginning and after the end of activities in the units. For analysis, routine techniques were used, which showed the presence of Staphylococcus aureus, Escherichia coli, Pseudomonas aeruginosa, Klebsiella spp, Candida spp, Penicillium spp, Epidermophyton spp, Aspergillus fumigatus, Aspergillus niger, Aspergillus spp, Cephalosporium spp, Cladosporium spp, Trichophyton rubrum, and Trichophyton spp. Results indicated a need for improving hygienic conditions, suggesting that water might be a contamination source in the evaluated units.

KEY WORDS: hydrotherapy, water, microorganisms, bacteria, fungi.

\section{CORRESPONDENCE TO:}

MAURO FONTES PERESTRELO, Rua Vicente Celestino, 496, apto. 101, 26525530, Nilópolis, Rio de Janeiro, Brasil.

Email: mauro perestrelo@hotmail.com. 


\section{INTRODUCTION}

In hydrotherapy, water is used in the treatment of several illnesses. However, it might present microorganism due to lesions in the patients or contamination of the source. Also, several equipments used favor the presence of microorganisms, reason why some caution is required. When the necessary measures are not taken, treatment represents risks to the public health $(6,7)$.

\section{MATERIALS AND METHODS}

Thirty samples of $5 \mathrm{ml}$ water were weekly collected from September 2001 to June 2002 in hydrotherapy units located in the counties Nilópolis and Nova Iguaçu, Rio de Janeiro State, Brazil. Samples were divided into two groups: Group A - collected before the beginning of the units activities; and Group B - collected after the end of the units activities. They were collected following hygienic recommendations and placed in assay tubes. In laboratorial conditions, samples were centrifuged at 2,500 rpm for 20 minutes; the sediment was plated on Thioglycollate medium, which was soon incubated at $37^{\circ} \mathrm{C}$ for $24 \mathrm{~h}$, and also on Sabouraud Dextrose Agar, incubated at room temperature until growth of the microorganisms occurred. The colonies obtained in Thioglycollate medium were plated on Bacto-EMB agar (Teague), Blood agar, Chapman agar and Pseudomonas selective agar and incubated at $37^{\circ} \mathrm{C}$ for 24 hours. Colonies of bacteria and fungi were identified according to colonial and stain characteristics and by biochemical and serological tests (BioMerieux Vitek system).

\section{RESULTS}

Tables 1, 2 and 3 show that almost all samples from both counties were contaminated but without the prevalence of a particular microorganism (Chi-square; $p>0.05)$.

The microorganisms found in the samples were indicated in Figures 1 and 2, and the most frequent were Staphylococcus aureus, Escherichia coli, Pseudomonas aeruginosa, Candida spp, Penicillium spp, and Epidermiphyton spp. 
Table 1: Frequency of samples positive for bacteria and fungi in the hydrotherapy units evaluated in two counties from Rio de Janeiro State, Brazil.

\begin{tabular}{l|c|c|l|l}
\hline & \multicolumn{4}{|c}{ Positive samples } \\
\hline Counties & N. & $\%$ & Valid \% & Cumulative \% \\
\hline Nilópolis & 47 & 55.29 & 55.29 & 55.29 \\
\hline Nova Iguaçu & 38 & 44.71 & 44.71 & 100 \\
\hline Total & 85 & 100 & 100 & \\
\hline
\end{tabular}

Table 2: Frequency of positive samples according to the collection period in the hydrotherapy units evaluated in two counties from Rio de Janeiro States, Brazil.

\begin{tabular}{l|c|c|l|l}
\hline & \multicolumn{4}{|c}{ Positive samples } \\
\hline Groups & N. & $\%$ & Valid \% & Cumulative \% \\
\hline A & 12 & 14.12 & 14.12 & 14.12 \\
\hline B & 73 & 85.88 & 85.88 & 100 \\
\hline Total & 85 & 100 & 100 & \\
\hline
\end{tabular}

Group A: samples collected before the beginning of the activities in the units Group B: samples collected after the end of the activities in the units

Table 3: Frequency of samples negative or positive for fungi or bacteria in the hydrotherapy units evaluated in two counties from Rio de Janeiro State, Brazil.

\begin{tabular}{l|l|l|l|l}
\hline Samples & N. & $\%$ & Valid \% & Cumulative \% \\
\hline 0 & 1 & 1.18 & 1.18 & 1.18 \\
\hline 1 & 55 & 64.71 & 64.71 & 65.88 \\
\hline 2 & 29 & 34.12 & 34.12 & 100 \\
\hline Total & 85 & 100 & 100 & \\
\hline
\end{tabular}

$0=$ Negative samples

$1=$ Samples positive for bacteria

$2=$ Samples positive for fungi 


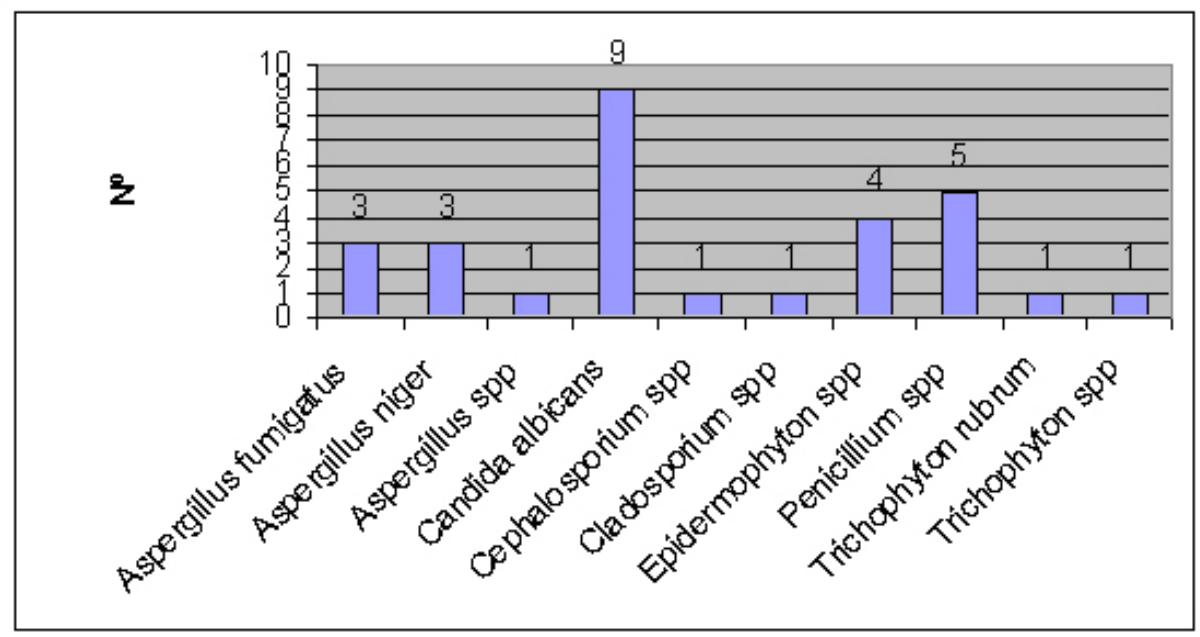

Figure 1: Frequency of fungi species reported in the hydrotherapy units evaluated in two counties from Rio de Janeiro State, Brazil.

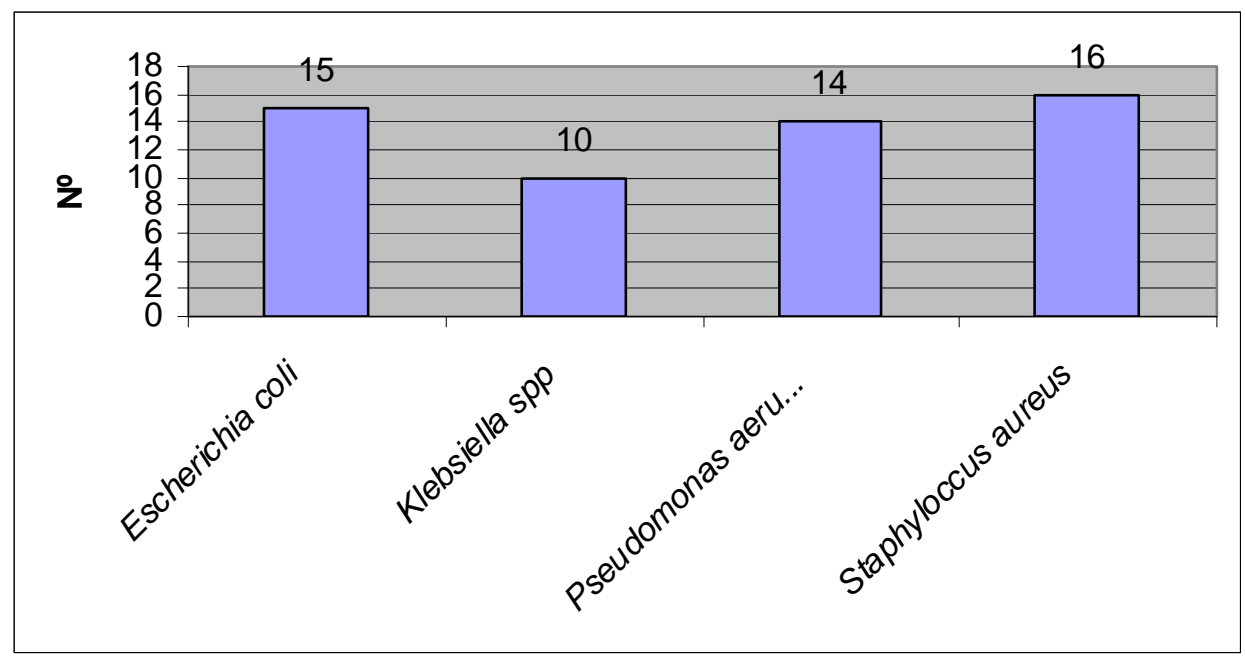

Figure 2: Frequency of bacteria species reported in the hydrotherapy units evaluated in two counties from Rio de Janeiro State, Brazil.

\section{DISCUSSION}

Water contamination was previously reported to be a risk to the public health $(6,7)$. Andrade et al. (1), Fantinato et al. (5), and Doyle (4) demonstrated the presence of microorganisms even after cleaning the equipments used in hospitals. These data pointed out that the lack of attention in the pretreatment of patients allows the presence of several microorganisms including Gram-negative bacteria which, when persistent for lingering periods, can be responsible for approximately $40 \%$ of infections. Spread of these microorganisms is facilitated when immunocompromised 
patients are involved; however, healthy individuals can serve as asymptomatic carriers.

Contamination of public water supply in the counties studied $(2,3)$ with Pseudomonas aeruginosa and Candida albicans was corroborated by reports of Fantinato et al. (5), who showed the presence of microorganisms in equipments due to the lack of cleaning and care with the patients, indicating inconsistency in the microbiological monitoring routine. Thus, it is suggested the need of further research on the development of routine methods to avoid future problems.

\section{REFERENCES}

1 ANDRADE D., ANGERAMI ELS., PADOVANI CR. Condição microbiológica dos leitos hospitalares antes e depois de sua limpeza. Rev. Saúde Pública., 2000: $34-42$

2 CAVALHERI NA., BRAMORSKI A., TAVARES LB. Avaliação da presença de Pseudomonas aeruginosa em águas potáveis consumidas no município de Blumenau - SC. Cent. Pesq. Proc. Alim., 1996, 14 (1), 59-62.

3 D'AGUILA PS, (1996). Pseudomonas aeruginosa como indicador em análises bacteriológicas de águas de abastecimento público. 1996. [Dissertation Masters of Science in Public Health]. Rio de Janeiro: FIOCRUZ/Escola Nacional de Saúde Pública, 1996.

4 DOYLE MP. Escherichia coli 0157:H7 and its significance in foods. Int. J. Food Microbiol., 1991, 12, 289-302.

5 FANTINATO $V$, SANTOS EB, UNTERKIRCHER CS, JORGE AOC, SHIMIZU MT. Descontaminação da água de equipos odontológicos através de antisséptico. Rev. Bras. Odont., 1995,12 (2), 6-8.

6 LIMA EO, CHAVES LM, OLIVEIRA NMC, (1994). Isolamento de dermatófitos geofílicos da região litorânea de João Pessoa, Paraíba, Brasil. An. Bras. Dermatol., 1994, 74 (2),127-32.

7 RUSSO E, CARVALHO RC, LORENZO JL, GARONE NETTO N, CARDOSO MV, GROSSI E. Avaliação da intensidade de contaminação de pontas de seringa tríplice. Pesqui. Odontol. Bras., 2000, 3 (14), 28-31. 